\title{
Tonus, Leonardo (2021), Diários em mar aberto. São Paulo, Folhas de Relvas Edições
}

\section{Recensão}

\author{
diante da inutilidade do gesto \\ resta a escrita de uma urgência \\ de fazermos pouco, \\ mas com todas as nossas forças.
}

Leonardo Tonus

Diários em Mar Aberto é o mais recente livro de poemas de Leonardo Tonus, professor na Sorbonne Université, com vasto currículo de investigador nas áreas da literatura brasileira, literatura comparada e teoria da literatura, e de mediador cultural, tendo sido inclusive curador do "Salon du Livre" de Paris em 2015, e fundador do festival anual "Printemps Littéraire Brésilien", que tem como objetivo central difundir a cultura lusófona e as suas literaturas, promovendo a sua efetiva leitura e discussão, desde logo junto dos estudantes universitários.

Existe toda uma tradição de académicos com obra literária paralela, seja na área da poesia, da ficção, do teatro, ou no domínio de um ensaísmo crítico a transbordar para o registo poético ou ficcional. Nalguns casos, será mesmo preferível falar de escritores paralela e circunstancialmente professores, para quem a docência representou ou representa, além do regular "ganha-pão", uma plataforma de (auto-)reflexão e de comunicação, ainda que indirecta, da sua carreira literária. Faço esta ressalva como constatação e não como um julgamento de valor ou de atitude, uma vez que me parece pertinente proceder a uma prévia divisão de águas. Nesse sentido, é importante começar por destacar que no caso destes Diários em Mar Aberto estamos perante um livro de poemas de alguém que se tem afirmado, antes de mais, como professor e investigador, cujo interesse nos fenómenos migratórios e nas exclusões a eles associados remonta pelo menos ao doutoramento que realizou em torno do autor de Contos de um Imigrante (1956), um escritor brasileiro de origem polaca e ascendência judaica (Samuel Rawet face à l'exclusion: représentation, poétique et éthique de la non-appartenance (2003). Ademais da pesquisa e pro- 
dução crítica mais habituais em contexto académico, ainda este ano Leonardo Tonus organizou e (co)moderou on-line, o "Projecto Migra", reunindo ao longo de vários meses e várias sessões mais de 80 escritores, artistas, cineastas, dramaturgos, ilustradores, investigadores e outros agentes da sociedade civil oriundos de diferentes quadrantes geográficos e linguísticos.

Ora, apesar desta já extensa carreira universitária, é bastante recente a revelação de Leonardo Tonus no domínio da escrita poética. O seu primeiro livro de poemas - Agora Vai Ser Assim - data de 2018, a que se seguiram Inquietações em Tempos de Insônia (2019) e, em meados de 2021, Diários em Mar Aberto. A derivação discursiva de Leonardo Tonus nada tem, pois, a ver com o cultivo de uma carreira literária paralela, como acontece com os atrás designados escritores-professores, nem aqueles três livros resultam de qualquer compilação tardia de poemas escritos ao longo dos tempos. Numa entrevista de 2019 à revista Cult, ${ }^{1}$ Leonardo Tonus admitiu existir uma forte ligação entre o estupor causado pelos actos de terrorismo em Paris ou a catástrofe social, política e ecológica no Brasil, e a sua estreia na edição de poesia própria. Contudo, nem era necessário recorrer ao paratexto autoral para perceber o quanto a poesia de Leonardo Tonus é historicamente motivada, e como ela representa uma inflexão no registo discursivo do professor-investigador, que não nos seus eixos temáticos, uma vez que continua a desenvolver-se em redor do trânsito de pessoas e de discursos. Essa constitui, de facto, uma inquietação permanente de Leonardo Tonus que, longe de estar circunscrita apenas ao domínio do intelecto ou da profissão, se configura igualmente como inquietude íntima, existencial, do indivíduo, do cidadão e do próprio sujeito da escrita.

Se o título do primeiro livro já apontava para a ideia de viragem - Agora Vai Ser Assim -, o poema de abertura destes Diários em Mar Aberto vem reiterar esse significado intratextual de mudança de lugar ou de migração enunciativa, desenvolvido depois nos restantes poemas que são atravessados por diferentes trânsitos migratórios. Veja-se como sob o título "resposta ao tempo que não para" [sic], Leonardo Tonus anuncia, logo à partida, o tipo de descolagem ou de abandono que estão em jogo nesta escrita migrante:

$$
\begin{array}{r}
\text { migrar: } \\
\text { dos protocolos } \\
\text { desconstruir a estrutura } \\
\text { até destruir os trilhos } \\
\text { que atropelam os destinos do sentido, }
\end{array}
$$

da escrita. (p.9)

A consciência da insuficiência, se não mesmo frustração provocada por alguns discursos especulativos e respectivos chavões quando confrontados com um "estado do mundo" ferido de convulsões, mudanças aceleradas, gestos desesperados, discursos de violência e políticas discriminatórias - em especial para estrangeiros, migrantes, refugiados ou minorias sexuais -, leva a que este professor-investigador se desinstale de um discurso repetitivo e amorfo, ao mesmo 
tempo que (se) questiona sobre o sentido de um conhecimento enredado em si mesmo e completamente divorciado de uma práxis: "Como se desvencilhar da filosofia / que nada concebe, que só concebe vida, sem vida, / que não se concebe enquanto prática de vida? // estaremos condenados a nos equilibrar / em suas ridículas pernas de pau?" - pergunta o poeta (p. 62).

Por aqui se poderá logo inferir que esta escrita poética surge alinhada com a crítica e abandono da exclusividade do regime estético da literatura, tendência essa que se tem acentuado, inclusive no campo literário francês, com o qual Leonardo Tonus, há 30 anos radicado em França, está naturalmente em contacto. Não obstante, continua a escrever em português e os seus livros são publicados no Brasil, o que não deixa de ser relevante em termos de intervenção, porque esta desenvolve-se ao mesmo tempo na distância e na proximidade quer da língua, quer do tecido político e sócio-cultural do seu país de origem.

Alexandre Gefen, autor de L'Idée de littérature. De l'art pour l'art aux écritures d'intervention (2021) não teria certamente dúvidas em integrar esta inflexão poética de Leonardo Tonus no domínio pluriforme das "escritas de intervenção", assentes naquilo a que chama um "compromisso de atenção" (engagement attentionnel) (Gefen 2021: 217) a determinados aspetos da realidade contemporânea. A esse compromisso, o autor de Diários em Mar Aberto chama urgência - "a minha urgência" - que surge declinada em forma de blocos de prosa telegráfica, com proposições inequívocas e, ao mesmo tempo, denunciadoras:

a minha urgência é a urgência dos mais de 65 milhões de pessoas forçadas ao desterro. dos 10 milhões de apátridas privados de nacionalidade. Dos quase 23 milhões de refugiados sem acesso à educação. à saúde. à liberdade de circulação. (p. 33)

Este poema faz-se acompanhar de uma longa nota de rodapé, onde Leonardo Tonus começa por traduzir a epígrafe, que mais não é do que a declaração de um agente de patrulha da fronteira entre os EUA e o México, tão escandalosamente desumana que se tornaria viral. As notas autorais de rodapé, em complemento informativo ou contextualizante dos poemas, remetendo ora para acontecimentos recentes, ora para declarações de políticos nomeados como Jair Bolsonaro, Donald Trump ou Matteo Salvini, ora para algumas citações de obras de outros autores, conferem à escrita poética de Leonardo Tonus um inegável cunho testemunhal da actualidade. No entanto, essa vertente pressupõe ou exige ser também equacionada com as relações que os poemas estabelecem ou induzem com outros momentos históricos ou com outros espaços geográficos, e a partir das quais aquilo que surge como manifestamente circunstancial deixa de ser apenas uma circunstância pontual. Isso mesmo é sugerido pelo título "em todos os tempos" do poema acima citado, enquanto aquilo que acontece noutros poemas é que o seu carácter datado, por vezes até ao detalhe das horas, coexiste com a reelaboração desse instante mediante a repetição das palavras, o ritmo dos versos e/ou à condensação das imagens. Com efeito, esta poesia inscreve-se nessa tensão entre o máximo de atenção ao "estado do mundo" e o máximo de propagação de sentidos que potencialmente rompem ou ultrapassam esse status quo que nega a humanidade de cada indivíduo. 
É na tensão e na hibridez discursiva que ressaltam dos poemas de Leonardo Tonus que reside a meu ver o seu maior potencial quer de abertura enunciativa, quer de alargamento cognitivo das realidades migratórias, tanto mais que uma e outro são feitos a partir da focalização de experiências triviais, dos corpos humilhados, em suma, de todas aquelas histórias particulares "que ninguém ouve" (p. 35), ou daqueles números a que já ninguém parece ser sensível. São essas invisibilidades que o poeta nos impele a olhar de frente, tal como acontece em "na hora da muda / sabiá não canta", um poema cujo lirismo encantatório se expande por um conjunto de blocos sincopados de texto, onde se parte de um desafio aparentemente apaziguador e inócuo à imaginação:

imagine o mar. um mar. imagine o seu mar. imagine um mar para além do mar. imagine o mar para além de tudo o que é o mar. de tudo o que você conhece de mar. Tudo o que se identifica como mar. no mar. imagine o seu mar, além-mar. (p. 67)

para depois chegar ao seu fulcro, que revela ser todo um percurso até à visão da profundidade obscena "desse mar" que, no início, poderia ser confundido com uma simples e vaga imagem, mas que afinal representa o mar-cemitério de cada um de nós:

agora, imagine esse mar numa tarde de outono.

o mar e suas folhas de outono.

um mar de folhas de outono.

33.293 folhas que navegam o mar.

que se perdem ao mar

folhas que se afogam

no seu mar. (p. 69)

Ao revelar a origem e o significado do número adiantado no poema, a nota de rodapé apensa ao final do poema rompe completamente com um lirismo que poderia ser anestesiante, tornando além disso inevitável a nossa queda no abismo da mais cruel realidade a montante e a jusante do poema: o número extraordinariamente elevado de mortes de migrantes nas águas do mar Mediterrâneo.

Ainda no domínio do hibridismo, parece-me importante também salientar o modo como o poeta convive aqui com o tradutor, embora essa forma de enunciação e subjectividade em trânsito não ocorra apenas quando Leonardo Tonus traduz do italiano, do francês ou do inglês para o português, sem contudo obliterar - registe-se - essas línguas do seu próprio texto. O lado tradutor do poeta manifesta-se também quando ele empresta voz àqueles que (já) não a têm; quando lhes interpreta os gestos ou quando transpõe para outro plano o seu discurso titubeante (como acontece num poema impressionante intitulado "sempre há uma primeira vez", pp. 71- 
73); quando comunga da alteridade do mundo e dos seres humanos que nele transitam em busca de um lugar próprio de dignidade, ou quando transporta para o presente memórias e pós-memórias da imigração que marcou e marca a vida familiar de tantos indivíduos, inclusive deste neto de imigrantes italianos e portugueses que rumaram para o Brasil nos inícios do século XX.

Embora Diários em Mar Aberto inclua traços de "pós-memória", no sentido que Marianne Hirsch começou por atribuir ao conceito, e que tão profícuo se tem revelado nas artes contemporâneas, não considero que o trabalho de pós-memória seja o núcleo central deste livro. É verdade que Leonardo Tonus recorre a memórias familiares, inclusive a passagens de documentos sobre a imigração na primeira metade do século XX, que fazem parte do seu arquivo familiar, mas Diários em Mar Aberto não é um livro que se apresente nem que se resuma a um trabalho poético de anamnese pessoal ou familiar. Pelo contrário, a história familiar de imigração surge não apenas fragmentada como embutida nalguns momentos destes diários de trânsitos, uma história que o poeta vai revisitando ou vasculhando como "caixas sem ponteiros" (p. 28) dentro de uma mesa de fórmica no centro da sala, um móvel que, tal como a memória, é deslocado de forma quiasmática entre pretérito imperfeito e presente do indicativo, entre presença e ausência. Ainda a este respeito, parece-me bastante simbólico o facto de o poema mais autobiográfico surgir apenas no final do livro, parecendo assim sugerir que a linhagem de imigração - "dor legada / em carne / viva" (p. 96) do próprio poeta, que remonta a uma travessia do Atlântico levada a cabo em Setembro de 1927, não representa nem o princípio nem a causa directa destes "Diários", embora tão-pouco lhes seja alheia, "porque no início / já era o caminho", tal como o poeta escreve na margem de uma das suas páginas finais.

Depois da dedicatória inicial - "à nous qui cessons de devenir humains" - é apenas no fecho do livro que Leonardo Tonus volta a utilizar directamente a língua francesa: "Il ne faut pas admettre les choses / Il faut faire des révolutions", pormenor de composição que talvez possa simbolizar a cápsula linguística e a tradição revolucionária a ela associada, em que é levado a mover-se este migrante lusófono. Mas independentemente da língua em que surge escrito, o mais importante é sem dúvida o apelo à mudança para que tanto dedicatória como "epílogo" apontam. Sob pena de esta inflexão poética de Leonardo Tonus incorrer na mesma tentação de uma auto-complacência paralisante contra a qual se insurge, não se pode, pois, ver nesta poesia senão um sinal mais de impermanência, uma etapa na transitoriedade, que não uma espécie de apogeu discursivo.

Dentro da sua deliberada randomização de espaços geográficos, sociais, académicos e artísticos, Leonardo Tonus vai certamente continuar a indagar mais configurações discursivas das migrações e a explorar outras possibilidades tanto de "partilha do sensível" (Rancière) como de intervenção, que poderão passar pela articulação com outras expressões artísticas, como aliás já acontece em certa medida nestes Diários em Mar Aberto, por via da presença de desenhos de grande sensibilidade expressiva do jovem designer Vítor Rocha, de que evoco aqui dois exemplos: 

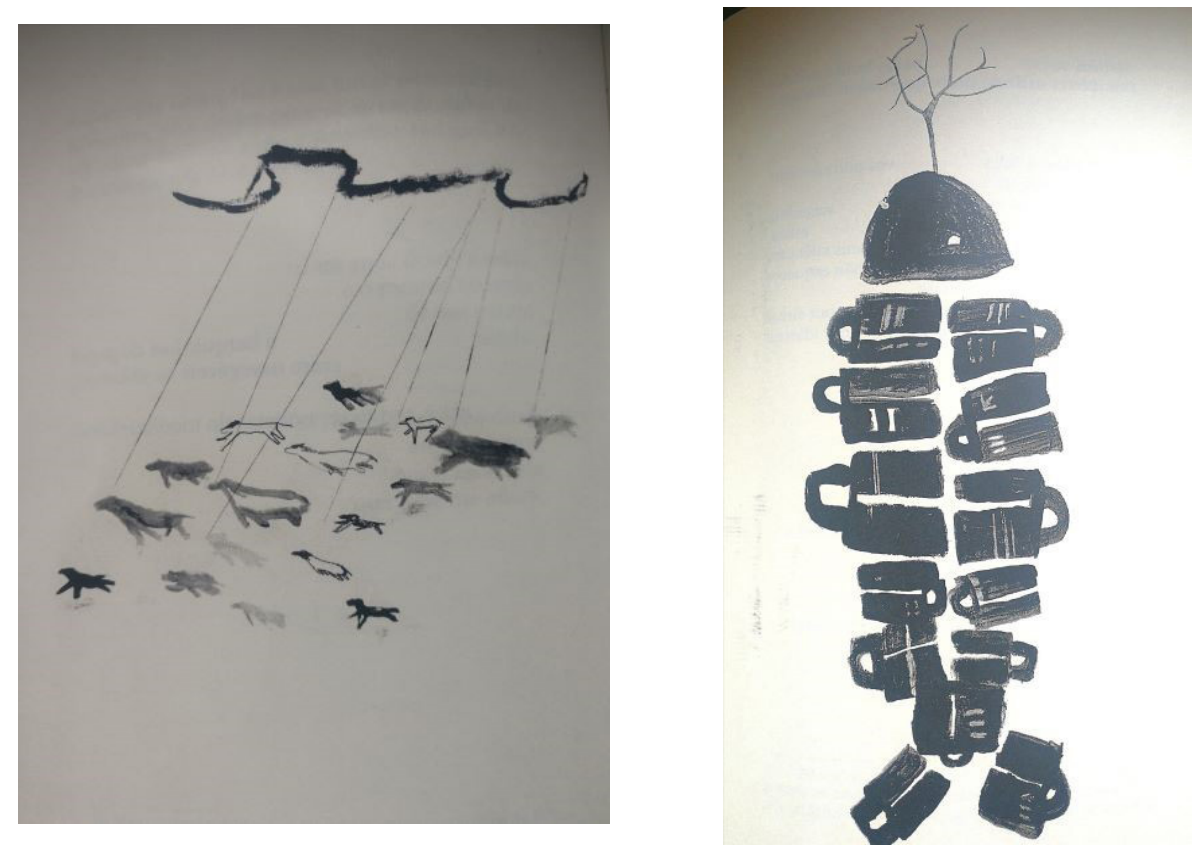

Diálogos que, mais do que ilustrarem, exponenciam as inquietações que extravasam das palavras. Afinal, que mais pode fazer o professor-investigador-poeta senão persistir na sua vocação relacional, deixando que em si mesmo se confrontem o sujeito distanciado e o sujeito vulnerável como faúlha em trânsito no mundo que o/nos rodeia? 


\section{NOTAS}

* Ana Paula Coutinho é Professora associada do Departamento de Estudos Portugueses e Românicos da Faculdade de Letras da Universidade do Porto, onde tem lecionado sobretudo nas áreas da Literatura Comparada e dos Estudos Franceses. Doutorada em Literatura Comparada (1998) e com Agregação em Literaturas e Culturas Românicas (2010), sempre se dedicou à literatura contemporânea numa perspectiva comparatista, tendo nos últimos anos desenvolvido particular investigação no domínio das interculturalidades e das representações literárias e artísticas das migrações e do exílio. Integrou vários anos a Direcção do Instituto de Literatura Comparada (2001-2003; 2012-2015; 2015...) e é actualmente a sua Coordenadora Científica. Coordena igualmente a base digital Ulyssei@s. Membro colaborador do CRIMIC (Université Paris IV), colabora ainda com o Programa Non-Lieux de l'Exil (Collège d'Études Mondiales - FMSH). É vice-presidente da Alliance Française do Porto. Tem vários artigos publicados em revistas e outras publicações colectivas, nacionais e estrangeiras (Colóquio/Letras, Cadernos de Literatura Comparada, Revue de Littérature Comparée, Diogène, Gávea-Brown, Carnets, Latitudes: Cahiers Lusophones, Intercâmbio...). Dos livros publicados ou editados, destacam-se António Ramos Rosa. Mediação Crítica e Criação Poética (Quasi Edições, 2003. Prémio Ensaio Pen-Club); Lentes Bifocais - Representações literárias da Diáspora Portuguesa (Afrontamento, 2009), Passages et Naufrages migrants. Les fictions du détroit (com Maria de Fátima Outeirinho e José Domingues de Almeida), Paris, Harmattan, 2012; Nos \& leurs Afriques. Images identitaires et regards croisés Constructions littéraires fictionnelles des identités africaines cinquante ans après les décolonisations (com Maria de Fátima Outeirinho e José Domingues de Almeida) Frankfurt, Berlin, Peter Lang, 2013; Marguerite Duras. Palavras e Imagens da Insistência, ILCML, Colecção Libretos, 2015.

${ }^{1}$ Cf. https://revistacult.uol.com.br/home/leonardo-tonus-entrevista/ [consultado a última vez em 21.11.2021] 